УДК $111.11 / 12$

DOI: $10.32837 /$ apfs.v0i25.878

Алексей Аркадиевич Ивакин

доктор философских наук, почётный профессор

Национальный университет «Одесская юридическая академия», г. Одесса, Украина

\title{
ОПОРА НА КОНГЕНИАЛЬНОСТЬ ИДЕЙ КАК УСЛОВИЕ ПОСТРОЕНИЯ ЦЕЛОСТНОЙ КАРТИНЫ МИРА
}

\begin{abstract}
Аннотация: Основываясь на своей современной целостной картине мира, автор статьи подбирает (начиная с времён возникновения философии) историческую «цепочку» философских идей, конгениальных, то есть близких по духу и образу мыслей, как друг другу, так и мировоззрению самого автора. Такая «подборка» идей имеет своей целью нахождение своеобразной опоры для подтверждения истинности авторской позиции, а также для ее дальнейшей конкретизации. Работа эта обязательно подразумевает необходимость анализа и интерпретации избранных автором идей, высказанных зачастую в своеобразной оригинальной терминологии, за которой скрывается принципиальная схожесть разновременных целостных картин мира. Автор приходит к выводу, и обосновывает его, что наиболее продуктивной и перспективной является целостная картина мира, базирующаяся на принципах объективного идеализма.
\end{abstract}

Ключевые слова: мир, конгениальность, апейрон, логос, идеальное, разум, человек, объективный идеализм.

После долгих лет размышлений о мире и о месте в нем человека я решил подвести им итог в виде хотя и схематичной, но целостной картины мира, опирающейся на идеи и выражающие их высказывания философов и философствующих представителей науки и теологии.

Иными словами, в изречениях разнообразных мыслителей я в данном случае отдаю предпочтение тем, которые я считаю конгениальными, то есть близкими по духу, по образу мыслей, моему видению мира. А это значит, что все эти изречения в той или иной степени конгениальны и между собой. Для того, чтобы выявить и доказать их конгениальность, приходится интерпретировать то или иное понятие или изречение, излагая его содержание не совсем так, а то и совсем не так, как оно было сформулировано самим его автором. Вполне естественно, что я при этом вынужден использовать не только исходные высказывания, но и их более поздние интерпретации и комментарии. Главная проблема при этом состоит в том, чтобы всячески избегать своего собственного произвола. Не всегда это получается. Однако для того, чтобы, по возможности, все же не допускать ошибок или же исправлять уже допущенные, надо всегда стараться почувствовать в анализируемом высказывании то, что его автором в буквальном смысле не говорится, но как бы просится быть высказанным. Это - одно из важнейших требований к интерпретатору со стороны классиков философской герменевтики Мартина Хайдеггера и Ганса Георга Гадамера. Причем, если первый из них акцент ставит на умении исследователя найти, увидеть великое в высказывании великого мыслителя и своеобразно это великое преобразовать, «перетворить», то второй как раз требует, чтобы высказываемая новация носила в чем-то принципиальное внутреннее сходство с оригиналом, а не была бы, грубо говоря, полной «отсебятиной». И поэтому естественно, что для выполнения указанных требований необходимо развивать в себе умение находить и использовать неочевидную, 
скрытую конгениальность различных понятий и изречений, постоянно сопоставляя при этом древние картины мира с более поздними и современными.

Итак, свою собственную целостную картину мира я стараюсь развернуть и обосновать как окончательный для меня на данный момент результат анализа и синтеза множества разнообразных идей, возникших в историческом интеллектуальном коллективном творчестве.

В связи с этим понятно, что эта картина мира имеет весьма продолжительную историю своего формирования и в какой-то мере принадлежит также и некоему множеству философов, разделяющих со мною основные принципы её логического строения. Следует отметить, что она, эта картина, не может, конечно, претендовать на роль абсолютной истины в последней инстанции, хотя каждый из причастных к ней авторов наверняка был в свое время убежден в истинности тех или иных основных составляющих ее моментов.

Однако поскольку истина, как известно, есть процесс, то для меня важнее уверенность в том, что история создания анонсируемой здесь целостной картины мира - это история неуклонного приближения запечатленного в ней знания к истинной логике устройства Мира.

Итак, сказанное говорит о том, что исходные принципы, без которых лично моё исследование теряет всякий смысл, заключаются в следующем: Мир принципиально и абсолютно познаваем. Мало того, познание мира человеку жизненно необходимо. Субъективность исследователя неизбежна, но надо помнить, что она является недостатком, идеал же, $\kappa$ которому надо постоянно стремиться, это объективность отражения действительности.

Родоначальники древнегреческой философии начинают именно так: c утверждения, что есть нечто всеобъемлющее, существующее вполне объективно, независимо от нашего взгляда на это «нечто». И оно есть логическое начало всего того, что было, есть и будет, и в том числе и - человека.

Называя таких философов, а именно - Анаксимандра, Гераклита и Парменида, «начальными» или «изначальными», Мартин Хайдеггер хотел этим сказать, что они не только исторические «начинатели» философского способа мышления, но и мыслят бытие мира как начало (архэ), которое «...не является произвольным порождением мысли. Начало не есть нечто, отданное на милость этих мыслителей, с каковым они в своем его постижении поступают так-то и так-то. Напротив, начало есть то, что само нечто совершает с этими мыслителями, ибо так захватывает их, что им приходится совершить предельное отступление перед бытием» [1, с. 27].

Однако далеко не все античные философы приняли содержание этого тезиса. Со временем появились софисты, устами Протагора провозгласившие, что мерой всех вещей является человек, причем - любой человек, и тем самым породили множество мыслителей, считающих историческое и логическое начало мира чемто, что они могут выбирать как один из ряда существующих вариантов и поступать с ним «так-то и так-то», то есть как угодно. Как можно видеть, данное направление принимает субъективность философского знания не как недостаток, а как норму.

«Начальные» же философы устами Гераклита заявили совершенно противоположное: они были уверены, что высказывают не свои собственные мудрые мысли, а, изрекая их, тем самым знакомят своих собеседников и слушателей с мудростью Логоса, то есть с мудростью устройства Бытия, с его содержательной логикой, которая не зависит от них, а главенствует над ними. По моему глубокому убеждению, это философское направление - несомненно самое драгоценное и перспективное направление во всей истории философии, ибо на его 
стороне логические аргументы и факты, поставляемые философии человеческой практикой и открытиями, совершаемыми наукой.

В итоге с гордостью должен сказать, что я причисляю себя к «начальной философии» на современной стадии ее развития. С гордостью - потому, что это философия Анаксимандра, Гераклита, Анаксагора, Платона, Аристотеля, Декарта, Спинозы, Лейбница, Шеллинга, Гегеля, Тейяра де Шардена, Хайдеггера и целого ряда других философов, отдающих дань почтения и признания первенства Высшему руководящему и направляющему Началу Бытия. Это - огромная и наиболее продуктивная часть философии, основополагающий принцип которой Объективный Идеализм.

Категорическое противостояние философии объективного идеализма софистике не означает, что она, в отличие от софистики, не ставит человека в центр своего внимания. Ставит, конечно, но, во-первых, не каждого, а во-вторых, абсолютной мерой всего сущего не считает. В античной философии лучше всех продемонстрировал такой диалектический подход к человеку великий Сократ: в центре внимания его философствования именно человек, но не любой, а тот, который живёт, познавая и применяя к своим поступкам подлинное для человека Благо. Через много веков такую точку зрения проповедовал, например, и Григорий Сковорода, считавший, что человек является началом и концом всякого философствования но, так сказать, не любой индивид, а человек «внутренний, вечный, бессмертный и Божественный».

Какое из двух вышеуказанных направлений более предпочтительно для человека? Судите сами. С одной стороны, начиная с появления софистов, в философии провозглашается субъективизм и плюрализм мнений, порождающих бесконечную борьбу интересов, заканчивающуюся зачастую победой в человеке, увы, не человеческого, а как раз анти-человеческого, начала. А с другой стороны, «начальными философами» упрямо постулируется, что Одно есть Всё и что это Одно порождает Всё и руководит им наилучшим образом, и поэтому человек, не желающий или не умеющий следовать этой Абсолютной логике Мира, в конечном итоге выбирает ошибочный путь, и от этого страдает и терпит поражение за поражением.

Отсюда следует, что человек для достижения своего подлинного счастья и успешного развития не только должен признать, что существует нечто Одно, но и то, что Оно диктует ему, а также всем окружающим его вещам и существам, некую единую обязательную логику поведения. Таким образом, мы должны признать тот факт, что существует единая Логика, которая лежит в основе всех прочих многочисленных содержательных и формальных логик.

Если действия неживой природы, а также - животных и растений осуществляются, выполняя Волю Бытия, стихийно, то человеку необходимо подключать мышление и любое дело начинать не с произвольного начала, а отыскивать начало как объективный универсальный закон и, отыскав его, согласовывать с ним также и свои практические действия. Есть законы физические, биологические и социальные, но есть также закон Логический. И он - самый важный закон среди всех законов и - главная логика среди других многочисленных логик.

Вот что говорит об этом М. Хайдеггер: ««Логика» понимает мышление как представление сущего в его бытии, как оно подставляет себя представлению в виде обобщенного понятия. Но как обстоит дело с осмыслением самого по себе бытия, то есть с мыслью, думающей об истине бытия? Эта мысль впервые достигает изначального существа «логоса», которое у Платона и Аристотеля, основателя 
«логики», уже затемнено и упущено. Думать наперекор «логике» не значит идти крестовым походом в защиту алогизма, это означает лишь задуматься о логосе и о его явившемся в раннюю эпоху мысли существе; это означает позаботиться для начала хотя бы только о подготовке подобного осмысления. Что могут нам сказать все сколь угодно разветвленные системы логики, если они заранее, даже не ведая, что творят, избавляют себя первым делом от задачи хотя бы только поставить вопрос о существе «логоса»?» [2, с. 211-212].

Из сказанного выше следует, что правильно мыслить человеку можно только на основе логики, почтительно «внимающей» логосу и исходящей из него как из главенствующей логики Бытия. «Мысль, если сказать просто, есть мышление бытия. У родительного падежа здесь двойной смысл. Мысль есть мышление бытия, поскольку, сбываясь благодаря бытию, она принадлежит бытию. Она - мышление бытия одновременно и потому, что, послушная бытию, прислушивается к нему» [2, c. 194].

Данная идея приоритета Логоса над любыми «логиками» и «законами» представляется настолько истинной и важной, что её следует отнести к исходной и одновременно - завершающей идее построения картины мира. В терминологии Гегеля, например, эта идея выступает как Абсолютная Идея, которая описывает своеобразный «круг кругов» под девизом «движение вперед то же, что и движение назад».

Задолго до этого конгениальное гегелевскому изречение высказал Гераклит: «Путь вверх и вниз - одно и то же» (фр. №60). А главное, что он сказал, что нет иной мудрости кроме той, чтобы признать, что Одно есть всё, и это «всё», в том числе и - человек, должно принимать этот факт неукоснительно. И ещё Гераклит оставил нам очень важное уточнение: «Мудрость заключается только в одном: признать разум как то, что управляет всем при помощи всего» (Фр. № 41).

Человек, признающий эту единственную мудрость, сам является мудрецом, ибо чувствует себя помощником высшего разума. Макрокосмос и микрокосмос, таким образом, диалектически совпадают.

Однако недостаточно убедить и утвердить себя в реальности и важности Логоса как исходного начала построения Общей картины мира. Чтобы не ошибиться и не подчинить себя какой-нибудь лукавой химере, надо глубоко осознать реальные моменты содержания Логоса, и многократно проверять их истинность на человеческой практике. И тут, снова повторю это, нас не должно смущать, что об одном и том же факте или явлении разные мыслители говорят поразному. Не надо поддаваться внешнему их различию, надо искать общее, скрытое за несхожестью их терминологии.

Начать эти поиски следует с понимания милетскими мудрецами (которых считают родоначальниками европейской философии) логической неоднородности исходного начала. Эта мысль подспудно присутствует уже у Фалеса, провозгласившего началом материю - воду. Мы смотрим на разнообразие мира, а на самом деле - все произошло из одного, из воды. Древние греки сильно удивились этой странной интеллектуальной находке известного мудреца и встали перед необходимостью решать (как оказалось, - веками) этот философский парадокс: как это «Одно» стало и становится «всем»?!

Анаксимен нам известен как скромный ученик Фалеса. Однако им, по сравнению с его учителем, сделан был определенный шаг вперед: его предложение иного «архэ» (воздух вместо воды) давало возможность увидеть в Одном - не безжизненную материю, но материю, изначально содержащую в себе возможность жизни.

(C) А. А. Ивакин, 2019 
Спрашивается, почему ни Фалеса, ни Анаксимена Хайдеггер не причислил к исходным, изначальным философам? Я предполагаю - потому, что материальное у них превалирует над идеальным. На переднем плане у них оказывается все же вещь, а не мысль и не смысл. Именно поэтому мне представляется, что особенный интерес из всех начальных вариантов «архэ» должен привлекать к себе апейрон Анаксимандра: здесь впервые как бы «поменялись местами» вещь и мысль.

Правда, большинство историков философии до сих пор думает иначе: они полагают, что апейрон - это бесконечное, беспредельное, но - всё таки «вещество». Эти историки не видят особой разницы между апейроном, водой, воздухом или огнем. Всё отличие одного вещества, а именно - апейрона, от других веществ состоит, якобы, «лишь» в том, что оно «бесконечно и беспредельно». И поэтому, согласно такой точке зрения, всех авторов перечисленных выше оснований бытия следует считать материалистами. Подобные классификаторы не видят своей собственной противоречивости в отождествлении данных видов «вещества», а ведь именно отсутствие определенности и ограниченности в апейроне говорит нам о том, что он - не вещество, ибо вещество с необходимостью имеет свой предел и общую границу с другим веществом. Я думаю, что Анаксимандр чувствовал это различие и поэтому апейрон у него беспределен, а вот созидаемые им вещи природы - те получают от него (апейрона) «предел», «форму».

Итак, вполне законно возникает мысль, что апейрон не вещественный, материальный, а именно нематериальный, то есть, идеальный, творец всего сущего, некий «программист и оценщик» правильности поведения любой вещи. И если это так, то апейрон - совсем не потому безграничен, неопределенен, что не оформлен, a, наоборот, - он именно потому ничем и ни в чем не ограничен, что оформлен безгранично и бесконечно многообразно, но не внутри себя, а - миром рожденных им вещей.

Как можно было бы суммарно интерпретировать сказанное выше с позиций современного видения? Позволю себе процитировать самого себя: «Следовательно, осуществить свою беспредельность Апейрон может только через определенность. Через любую определенную вещь, а особенно - через вещь мыслящую, то есть через человечество в его развитии. И тогда выходит, что апейрон, рассмотренный вместе с сотворенным и управляемым им космосом - это настолько многообразно (потенциально и актуально) оформленное Нечто, что именно его-то и следует назвать тем именем, которое придумал Аристотель - Форма всех форм. То есть Бог». [3, с. 133].

Надо сказать, что, хотя Аристотель употребляет слово архэ (начало) в смысле «руководящий принцип» лишь тогда, когда речь у него идет о началах какого-либо доказательства, тем не менее важно подчеркнуть, что то же самое, но уже в онтологическом смысле, присутствует у него именно в понятии «форма всех форм», конгениальном Анаксимандрову понятию «апейрон».

Я часто задаю себе вопрос, почему этим понятием по-настоящему не заинтересовались ни один из двух великих философов: ни Гегель, ни Хайдеггер. Почему, например, Гегель не увидел в апейроне отдаленный намёк на содержание своей «Науки логики», которое он гордо сравнивал с Богом, каким он есть «до» и «независимо от» сотворения Им мира?

Хайдеггер, как было сказано выше, ввел Анаксимандра в состав троицы «начальных» философов, однако понятие апейрон появляется в его статье «Изречение Анаксимандра» как бы мельком, как то, что им рассматривается на фоне мира вещей, порожденных и поглощаемых апейроном, но - не к самому 
апейрону. А ведь именно апейрон их делает такими, какими увидел и изобразил их в своей герменевтической статье Хайдеггер, то есть - обремененными некоторым предназначением, и требованием его исполнения.

Вспомним, однако, и общепринятое, традиционное понимание изречения Анаксимандра: «Из чего же вещи берут происхождение, туда и гибель их идет по необходимости; ибо они платят друг другу взыскание и пени за свое бесчинство после установленного срока» [4, с. 183]. Это - изречение Анаксимандра в переводе Германа Дильса, который Хайдеггер считал наиболее адекватным.

И вот это единственно дошедшее до нас изречение Анаксимандра Хайдеггер не просто переиначил, извлекая из него то, что, как ему казалось, «напрашивалось» на то, чтобы его высказал проницательный исследователь данного изречения. Нет, он счел его уже искаженным некими комментаторами, которые неверно его поняли как нечто малозначимое в силу его, якобы, антропоморфности и тривиальности: «В распространенном понимании это предложение (т.е. буквально понимаемое изречение Анаксимандра. - А.И.) говорит о происхождении и гибели вещей. Оно характеризует род этого процесса. Происхождение и гибель возвращаются туда, откуда они пришли. Вещи развиваются и разрушаются вновь. Поэтому они являют некий род плодосеменного хозяйства в равнопребывающем домострое природы» [5, с. 34-35].

Однако представляется, что Хайдеггер в данном случае несколько противоречит самому себе: поскольку он взял это изречение в качестве предмета своего герменевтического анализа и фактически нашел в нем начало поиска философами Логоса, то оно само по себе заслуживает право быть родоначальным изречением последующей цепи развивающих его, конгениальных ему понятий и учений. Ибо уже в этом традиционно понимаемом изречении существует великая идея, говорящая о том, что апейрон не просто создает и разрушает все вещи, но и управляет вещами и стихиями, дает им определенность и предназначение, неисполнение которых может (говоря человеческим языком) быть наказано тем, что они присуждаются к исчезновению.

Итак, эта важная мысль впервые была высказана не Гераклитом, не Парменидом, а именно исторически предшествующим им первым из трех начальных философов - Анаксимандром.

Посмотрим теперь, как далее развивалось, по-новому осмысливалось основное, внутреннее содержание учения Анаксимандра об апейроне, резко противопоставляющее абсолютно активную (планирующую и контролирующую) часть вселенной и часть, относительно пассивную, подчиненную первой.

Парменид в своем учении о бытии, как о единственно том, что безусловно и вечно существует, противопоставил его небытию и движению и отождествил его с сознанием. Анаксагор выдвинул тезис «всё во всём» и логически поделил мир на руководящий им Нус (Ум) и «подобочастные» (гомеомерии), посредством которых Нус этим миром управляет. Платон своим учением об идеях пришел к выводу, что, с одной стороны, существует истинный мир - мир идей и, с другой стороны, - так называемое «иное бытия», то есть бытие несовершенных и бренных вещей. Платоновское же понятие «Идея Блага» и его авторская трактовка этого понятия раскрывает перед нами соотношение мира «истинных», идеальных вещей, созидаемых «Идеей блага» и - человека, способного, благодаря наличию истинных вещей, истинно познавать мир. Таким образом, Платоном высказывается уверенность, что Мир познаваем и, мало того, в этом состоит высшее Благо как для мира, так и для человека

(C) А. А. Ивакин, 2019 
Так что выходит, что «апейрон», а также множество исторически более поздних конгениальных ему образов, это действительно объективный руководящий принции. Средневековые философы Бытием называли именно Бога - Творца и Руководителя созданного Им мира. И поэтому называли Его Природой Творящей. Чтобы принципиально отличать это абсолютное неизменное Бытие от пестрой, многообразной, постоянно изменяющейся Природы Сотворенной, некоторые теологи даже именовали Бога как « Великое Ничто». Разве не проглядывает в этих терминах «Апейрон» и «Форма всех форм»?

Важно отметить, что природа творящая рассматриваться изолированно от природы сотворенной не может. Можно сказать, что в определенной мере частично правы и «пантеист» Спиноза, и критикующие его теисты. Спиноза прав, что Природа - это и есть Бог, но в его концепции отсутствует Бог, который не есть природа, а есть, можно сказать, Идея Природы, та идеальная часть бытия, которая не-определённа, бес-предельна. Теологи-теисты правы в том, что Бог есть чистая форма всех форм, находящаяся за пределами мира, но в их концепции отсутствует сам мир, созданный Богом-Отцом и пронизанный его ипостасью - Святым Духом, инволюционно-эволюционно созидающим неживую, живую и мыслящую природу.

Серьезный вклад в конкретизацию картины мира, созданной философами античности и средних веков, внес Г.В.Лейбниц, и это, прежде всего, - его учение о монадах, его утверждение о предустановленной гармонии мира и о том, что наш мир - наилучший из возможных миров. Хочу отметить, что все эти его новации тесно связаны друг с другом. И действительно, мир наш создан наилучшим образом в силу его внутренней гармонии, заключающейся в том, что не только человек, но и каждое природное тело имеет своеобразную душу, которую Лейбниц называет монадой. Таким образом, «материальное» и «идеальное» - два атрибута спинозовской субстанции «Природа, или Бог» распространяются Лейбницем на все природные вещи. Он считает, что монады являются субстанциями сотворенными, производными, тогда как Бог является первичным Единством, или изначальной простой субстанцией. Бог создает не только монады, но и их гармоничное закономерное взаимоотношение, в котором «всякая монада по-своему есть зеркало универсума». Таким образом, по Лейбницу, важнейшим свойством, то есть атрибутом, универсума является отражение, высшей и развитой формой которого является сознание. Отражение объединяет и гармонизирует все вещи природы, причем это не пассивное отражение: оно вызывает изменение восприятий любой монады и соответственно - материальное действие тела, обладающее данной монадой.

Разве это не конгениально изречению Гераклита о Разуме, управляющем всем с помощью всего? Несомненно, конгениально, а если мысленно опуститься еще глубже в историю философии, то философия Лейбница так же конгениальна и изречению Анаксимандра о соотношении апейрона и созидаемой им природы. Связь разных пластов размышлений «об одном и том же» - о соотношении идеального и материального, разума и «плоти», руководящего и руководимого - со временем не прерывается, а лишь обогащается и конкретизируется.

Важным аспектом такого соотношения является намеченное Гераклитом противоречивое единство вечности Космоса и постоянной его изменчивости (что никак не могло быть воспринято Парменидом, считавшим, что одно отрицает другое). Согласно Гераклиту, Космос - это вечный огонь, мерами (то есть закономерно) возгорающийся и мерами затухающий. Задолго до появления первых эволюционистов, Гераклит подсказывает своим современникам и потомкам: 
направленное, закономерное, циклическое движение - это единственный способ осуществления вечности бытия.

Гегель, восторженно восклицавший, что нет такого положения в философии Гераклита, какое он не включил бы в свою Логику, изобразил Гераклитовы замкнутые в цикл метаморфозы - в форме так называемого «Круга кругов», в котором неживое, живое и мыслящее своими специфическими «малыми» кругами сменяют и одновременно дополняют друг друга, инволюционно вытекая из «Абсолютной Идеи» и эволюиионно завершая «большой круг» своего движения в той же Абсолютной Идее.

Меня могут упрекнуть в том, что я осовремениваю Гегеля, но как я мог бы еще иначе интерпретировать фразу Гегеля «...Единственно лишь абсолютная идея есть бытие, непреходящая жизнь, знающяая себя истина и вся истина» [6, с. 288], причем, глядя на неё уже глазами Пьера Тейяра де Шардена?.

В общем, соединяя воедино три конгениальные друг другу картины мира Гераклита, Гегеля и Тейяра, я отчетливо вижу, что первая стремится высказать то, что фиксирует в себе вторая, а обе они - высказать то, что отчетливо и талантливо рисует П. Тейяр де Шарден в своей теории «ортогенеза сознания», то есть его направленного развтия.

Правда, между Гегелем и Тейяром хронологически следует поставить ещё и Ф. Ницше, который хоть и не успел создать свой, по выражению Хайдеггера, «онтологический шедевр», но, как доказано в интерпретации того же Хайдеггера, внес свой вклад в коллективно созидаемую указанными выше мыслителями картину мира в виде черновых набросков учения о единстве понятий «воля к власти» и «вечное возвращение того же самого». Кратко назвать суть этого единства можно вездесущей и вечной соревновательностью всего сущего, порождающей отбор наилучших (считаю, что это свойство бытия замечено было уже Гераклитом). А еще важна высказанная Ницше, не всеми правильно понимаемая, идея Сверхчеловека. Думаю, вряд ли Тейяр де Шарден был знаком с незавершенным творчеством своего старшего современника Ницше, но несомненно то, что мыслил он в русле таких своих великих предшественников, как Гераклит и Гегель. Кстати, в любви и уважении к философии Гераклита неоднократно признавались и Гегель, и Ницше.

Тейяр де Шарден интересен уже тем, что является одновременно и выдающимся ученым, и теологом, и глубоким философом-диалектиком. Развивая эволюционное учение, он считает этот процесс целенаправленным и руководимым высшим разумом, движущая сила которого реализуется посредством диалектического единства тангенциальной и радиальной энергий, а цель которого определяется как сфера разума - ноосфера.

То, что у Гегеля обозначается как «Круг кругов», у Тейяра именуется восхождением от «литосферы» к «биосфере», а затем - к ноосфере». Слово «сфера», на мой взгляд, в данном случае даже удачнее, чем «круг», точнее.

Таким образом, путь духовного развития человека и человечества приобретает вполне зримую, материальную траекторию - восхождение к ноосфере. В результате сознание проявляет себя как действительный атрибут субстанции. И сразу же возникает вопрос, а зачем сознание нужно бытию, зачем мыслящий человек нужен Богу? Общий ответ напрашивается такой: для того, чтобы поддерживать гармонию, можно сказать, - тонус космоса: ведь Разуму нужны те, как говорил Гераклит, которые ему помогают, поскольку он управляет «всем с помощью всего». Таким образом, Высший Разум постоянно стремится как бы «выращивать» себе со-управленцев, со-творцов гармонии вселенной. 
Как можно видеть, каждая новация дополняет и конкретизирует ту или иную из предыдущих конгениальных ей картин мира. Работает принцип не «или - или», а «и - и». Всякий раз находится самое важное в предыдущей картине и творчески преобразуется, часто сопровождаясь при этом добавлением и гармоничным встраиванием в данную картину чего-то нового, до сих пор незамеченного. Так, в данном случае, Тейяр воспринял открытие Джеймсом Дана процесса «цефализации» и сделал его центральным моментом в своем теоретическом осмыслении и изложении «ортогенеза сознания». Мне же всегда хотелось доказать и добавить в картину мира Тейяра то, что направленное развитие сознания, по достижении человечеством состояния ноосферы, с необходимостью должно привести к возникновению сознания качественно иного, высшего уровня. Такое суперсознание я еще в молодые годы назвал «Объединенным Разумом». И до сих пор я совершенно уверен в том, что появление более высокого и эффективного способа мышления, по сравнению с современным человеческим, приведет к познанию того скрытого и тайного в мире, которое многими считается принципиально непознаваемым. И я даже нашел себе в этом вопросе великого и авторитетного союзника в лице Апостола Павла, писавшего в послании к Коринфянам: «Ибо мы отчасти знаем и отчасти пророчествуем; Когда же настанет совершенное, тогда то, что отчасти, прекратится» [1Кор. 13: 9, 10]. «Теперь мы видим как бы сквозь тусклое стекло, гадательно, тогда же лицем к лицу; теперь знаю и отчасти, а тогда познаю, подобно как я познан» [1Кор.13: 12].

Впрочем, когда мы пытаемся интерпретировать теологические тексты, нам следует иметь в виду, что в них присутствует и такой смысл, какой вполне доступен религиозной Вере и чувствам верующих и не доступен пониманию современного рационального мышления.

Мне казалось и кажется, что содержание канона Пресвятой и Живоначальной Троице конгениально философскому изображению Мира, руководимого Высшим Разумом, и что его можно буквально перевести на философский язык как своеобразное выражение процесса циклической инволюции-эволюции Природы от неживого - к живому и далее - к мыслящему. Конгениальность здесь действительно присутствует, однако все не так просто.

Согласно названному канону, Бог Отец не рождается и не исходит от другого Лица; Сын Божий предвечно рождается от Бога Отца; Дух Святый предвечно исходит от Бога Отца. Все три Лица по существу и свойствам совершенно равны между собой. Христос - Единородный Сын Божий, рождён «прежде всех век», «свет от света», вечно с Отцом, «единосущен Отцу». Всегда был и есть Сын, как и Святой Дух.

Mbl можем религиозный термин «Бог Отецу выразить рациональным философским понятием «Выссший Разум», «Дух Святый» - понятием «Энергии» (Григорий Палама, Тейяр де Шарден) как логическая сила развития Природы исходящая из Высшего Разума, «Сын Божий» - философским понятием «Идея и Идеал Божественной сущности человека», но что нам делать с понятием «Предвечно»? По-видимому, мы еще не способны охватить умом и чувством, идущий, с одной стороны, от «начальных» философов и, с другой стороны, от представителей религий Единобожия, принцип «Вечности» и «Предвечности».

Поэтому могу лишь предположить, в каком, в связи с этой проблемой, направлении должна развиваться философия, оставаясь в то же время «подлинной держательницей разума» (М. Хайдеггер).

Прежде всего, как я полагаю, мы должны уразуметь, что замыкание эволюционных событий в «цикл», в «круг», в «сферу» означает переход от «дурной 
бесконечности», характерной для пространственно-временного мира, - к миру вечности, в котором радикально изменяется привычная нам чувственно доступная, подчиняющаяся знакомым нам физическим законам Природа.

В мире вечности, например, нет исторических начала и конща, они имеют лишь логический характер. Это интуитивно понял Парменид, исходящий из неизменного бытия и, в связи с этим, отрицавший наличие движения. Его оппонент Гераклит тоже считал мир (космос) вечным, но признавал также и циклическое движение, которое и обеспечивает космосу вечность. Вечный огонь, мерами возгорающийся и мерами угасающий, остается, продолжает существовать вечно и поэтому начало и конец всех его метаморфоз не имеют чисто исторического значения. Это - «как бы» начало и конец. Именно так полагал и Рене Декарт, предупреждающий своего читателя, что, рисуя картину мира, он, лишь исходя из удобства, излагает её как историю, но на самом деле она - «как бы» история.

То же самое мы должны сказать и о «начале» в Евангелии от Иоанна: «В начале было Слово, и Слово было у Бога, и Слово было Бог», а также - и о «Предвечности» в каноне Пресвятой и Живоначальной Троице.

Важно также иметь в виду сложный вопрос о мгновенности и вездесущности информации и энергии, исходящих от Высшего Разума и, возможно от других мыслящих систем более низкого ранга, но более высокого, нежели человечество. Этим вопросом, как известно, занимался К.Э.Циолковский, и этим же вопросом в массовом масштабе интересуются современные ученые, то и дело сталкивающиеся с несомненным наличием определенных форм внешнего руководящего воздействия на зарождение и поведение биологических и социальных систем.

Времена табуирования указанных мною проблем как носящих, якобы псевдонаучный характер, уже прошли или проходят. Им на смену пришло время вполне осознанного и безусловного отказа от абсолютизации парадигмы стихийного детерминизма. Наука нуждается в парадигме Богоцентризма (В. П. Петленко), то есть в Парадигме Высшего Разума, способного решать задачи не путем случайного перебора, а путем одноактного акта творения...» [7]

Известный философ, в последние годы занимавшийся исследованием научного и вне-научного знания, содержащего в себе трактовку фактов наличия многочисленных следов земных или неземных загадочных цивилизаций А.А. Хамидов [8], выдвигает много интересных и убедительных гипотез. Среди них для заключительной части моей статьи особую важность представляет гипотеза о возможности существовании совершенно иной физики и соответственно физических законов, которых мы не знаем, но которыми пользовались исчезнувшие цивилизации.

Считаю вероятным, что названные новые подходы в науке позволят со временем понять такие явления в сфере Вечности, как отсутствие пространства и времени и соответственно - мгновенность информационной связи и практических действий. И то, что мы видим сейчас как бы через «тусклое стекло», станет для наших далеких потомков божественно ясным и понятным, ибо они наконец-то решат загадку «четвертого измерения», в котором существует Абсолют, Вечный и Вездесущий.

Итак, каким я вижу Мир. Заключение. Мир - это Вечный реально бытийствующий, живой и мыслящий, обладающий Высшим Разумом Космос. Его атрибутом, то есть неотъемлемым свойством, является гармония. Гармония заключается в слаженности, согласованности составляющих его состояний. В этом суть Абсолютной Идеи Космоса как вечного замысла Высшего Разума и вечного его воплощения, заключающегося в диалектическом единстве существования 
неживого, живого и мыслящего состояний бытия. Для постоянного сохранения этого гармонического триединства Высший Разум руководит всем с помощью всего, имея для этого вечную, сокровенную Логику (Логос), диктующую Высшую Волю (как надо быть, жить, мыслить) каждому специфическому состоянию бытия как его собственное призвание и предназначение.

Что касается человечества как носителя начального уровня сознания, то его предназначение - всячески способствовать превращению биосферы в ноосферу, для чего каждый человек отпущен на свободу стать и быть разумным и справедливым, то есть человечнылм. Исполнение этого предназначения награждается переходом в ноосферу как высшую форму разума и справедливости, неисполнение предназначения - наказуемо оставлением на обочине эволюции.

Согласно логосу, каждая вещь должна соответствовать своей идее (Платон). Стремление к такому соответствию Ф. Ницше выразил в понятии «воля к власти», то есть воля стать лучше, сильнее, совершеннее. Интерпретирую это следующим образом: стать лучше внутренне это значит - возможно более совершенно своим устройством и поведением, то есть материально, соответствовать своей идеальной сущности; соответствовать внешне это значит - лучше, чем другие, соответствовать окружающей среде, вписываться в неё, отражая ее в себе идеально и материально.

Таким образом, существование состояний бытия наполнено соревновательностью, ведущей к Отбору тех, кто наиболее способен к переходу из низших бытийных состояний - в более высокие. Соревновательность и отбор главное требование Логоса к неживому, живому и мыслящему бытийным состояниям.

В отличие от «дурной бесконечности» подлинная бесконечность осуществляется путем извечного замыкания этих трех состояний в инволюционноэволюционные циклы метаморфоз Идеального, именуемого Гераклитом - Огнем, Гегелем - Духом, Тейяром де Шарденом - божественной энергией, направленно преображаемой в психическое (в биосферу) и затем - в сознание (в ноосферу).

Итак, бытие любой вещи есть её соответствие своей идее в составе более крупной системы. Поэтому мы можем и должны говорить о бытии человека внутри Космоса и о божественности как высшей форме и стадии человечности. Эта осознанная причастность Человека к сути Абсолюта есть абсолютная истина. Однако истина может быть не только абсолютной, но и относительной. Таково бытие человека в системе человечества, в системе нации, народа, государства, а также - биосферы и литосферы. Но надо помнить, что все эти относительные истины обретают свою конкретность только в составе Абсолюта, в причастности Абсолюту.

Сказанное проливает новый свет на такую форму познания, как интуиция и вера. Интуиция - это метод совпадения настроя человеческого мышления с Логосом. Более понятной в этой связи становится идея Платона о том, что знание есть воспоминание. Ибо такое «воспоминание» не только, как я думал раньше, означает совпадение мысли индивида с идеями духовной культуры, но $u$ получение искомой информации от Святого Духа (Логоса), руководящего всем посредством всего, в данном случае - не только посредством духовной и материальной культуры, но и абсолютно непосредственно. Вспомним Сократа, постоянно беседующего со своим Даймоном.

Таким образом, Спиноза прав, выделяя и возвышая интуицию из других методов познания. Интуиция - это особый (высший) метод познания. Творческое воображение - это сотворчество человека с океаном Разума. Это - выход за 
пределы Мира человека (А. С. Арсеньев). Таким образом, мир человека - это не только духовный и материальный мир культуры, но - Мир Космоса.

Вера - это правильный настрой бытия человека в космосе. Настрой через Святого Духа. Это главное! Вот почему, как говорится в Евангелии, хула на Дух Святой - больший грех, чем хула на Сына Божьего. Это действительно так, ибо человек по своей воле теряет связь с Абсолютом, то есть опустошает и теряет свою душу бессмертную.

Важнейший вывод (и основание) моего мировидения - вечность Бытия (Бога, Космоса, Природы). Ибо только вечность доказывает разумность Вселенной. Вспомним: еще Парменид считал вечное бытие и мышление - одним и тем же.

Гармония мира носит предустановленный характер. Понятия «начало» и «конец» к апейрону (Абсолютному Духу) неприменимы. Временные и пространственные характеристики существуют лишь внутри природы сотворенной, ибо творящая Природа существует в вечности. Она есть Целое и Единое, которому доступен мгновенный информационный и энергетический контакт с любой точкой Вселенной. Она есть Вечность, где пространство и время находятся в снятом управляемом состоянии.

Философия - хранительница разума, рационального, но ей не следует чураться чувственного и иррационального способов идеального освоения мира. Эмпирический и мистический материал для мышления она должна брать с целью нахождения среди единичностей - конкретной всеобщности, то есть Идею вещи следует искать с помощью анализа материи вещи, но не по признаку одинаковости, а по признаку уникальности материального воплощения идеи вещи.

Современные ученые приходят к выводу, что Высший Разум требует от единичного человека развития его собственного разума, а от человечества разумного, справедливого устройства общества. Справедливость же устройства общества как раз и состоит в том, чтобы создавать условия для массового развития отдельных, индивидуальных сознаний. (И. Н. Острецов).

Важно подчеркнуть «механизм» эволюции и инволюции, их «логистику». Каждому человеку важно понять свою роль в «круге кругов», то есть осмыслить, зачем Богу нужен человек. Вспомним размышления и выводы Г.Сковороды о «сродном труде». Очень важно при этом уяснить себе, почему, вообще, человек должен быть человеком, то есть соответствовать своей сущности. И в чем состоит Высшая награда за достижение человеком такого соответствия.

Для большинства современных обществоведов характерно следующее заблуждение: глубинные причины политических и экономических перемен они ищут в классовой борьбе, в сговоре крупных групп транснациональных корпораций и т. д, то есть - исключительно в самом социуме. Глубинная же космическая суть людей и событий для них как бы и не существует.

Практика, как известно, критерий истины. Я с уверенностью могу заявить: только объективный идеализм как мировоззрение, основанное на объективном приоритете в мире - идеального, истинно отражает логическое строение мира и ведет нас к построению ноосферы, то есть - сообщества разумных и справедливых людей. Именно этот путь нам предписывает Божественный Логос. Все остальные формы идеализма и материализма обязательно содержат в себе «навязанный» человеку софистикой субъективизм. И не имеет значения как мы в лозунге «человек - мера всех вещей» истолковываем слово «человек»: как «индивид» или как «род людской». Результат будет один и тот же. Как сказал выдающийся философ Г.С. Батищев, любая форма субъективизма «...есть антропоцентризм, всегда глубинно противостоящий действительной объективной диалектике, 
которая царит во Вселенной и может питать собою постепенно раскрываемое и формируемое созидательно-творческое назначение человека» [9, с.27].

\title{
СПИСОК ИСПОЛЬЗОВАННЫХ ИСТОЧНИКОВ
}

1. Хайдеггер М. Парменид / Мартин Хайдеггер. - СПб: Изд. «Владимир Даль», 2009. - 384 с.

2. Хайдеггер М. Письмо о гуманизме / М. Хайдеггер // Хайдеггер М. Время и бытие : статьи и выступления / М. Хайдеггер. - М.: Республика, 1993. - С. 192-220.

3. Ивакин А.А. Единство Бога, человека и ноосферы: философское эссе /А.А.Ивакин. - Одесса : Феникс, 2012. - 244 с.

4. Фрагменты ранних греческих философов (Часть I). От эпических теокосмогоний до возникновения атомистики. - М.: Наука, 1989. - 576 с.

5. Хайдеггер М. Изречение Анаксимандра. / М.Хайдеггер / Мартин Хайдеггер. Разговор на проселочной дороге: сборник статей / М. Хайдеггер // М. Хайдеггер - М.: Высшая школа, 1991. - С. 133-145.

6. Гегель Г.В.Ф. Наука логики: в 3-х т. / Г.В.Ф.Гегель. - М.: Мысль, 1970 - 1972. -.- Т.№3. - 1972. - 373 c.

7. Кандыба В.M. Загадочные Сверхвозможности человека // Электронная библиотека научной литературы по гуманитарным дисциплинам [Электронный ресурс]. - Режим доступа : www.i-u.rulbiblio

8. Хамидов А.А. Научное и вне-научное знание: конфронтация и конвергенция: Монография. В 3-х частях. - Усть-Каменогорск, 2014.

9. Батищев Г.С. Введение в диалектику творчества. - СПб: РГХИ. 1997. $-464 \mathrm{c}$.

\section{ОПОРА НА КОНГЕНІАЛЬНІСТЬ ІДЕЙ ЯК УМОВА ПОБУДОВИ ЦІЛІСНӦ̈ КАРТИНИ СВІТУ}

\begin{abstract}
Анотація: Спираючись на власну сучасну цілісну картину світу, автор статті «підбирає» (починаючи 3 часів виникнення філософії) історичний «ланцюжок» філософських ідей, конгеніальних, тобто близьких по духу та образу думок, як одна одній, так і світогляду самого автора. Така «збірка» ідей має на меті відшукання своєрідної опори для підтвердження авторської позиції, а також для іï подальшої конкретизації. Робота ця обв'язково передбачає необхідність аналізу та інтерпретації, відібраних автором ідей, висловлених почасти у своєрідній оригінальній термінології, за якою криється принципова подібність різноманітних цілісних картин світу. Свою власну цілісну картину світу автор намагається розвернути і обгрунтувати як результат аналізу і синтезу множини різноманітних ідей, які виникли в історичній інтелектуальній колективній творчості. Автор виходить з принципу, що світ може бути цілком і абсолютно пізнаний. Пізнання світу є життєвою необхідністю для людини. Гносеологічним ідеалом, досягнення якого слід постійно намагатися, є об'єктивність відображення дійсності. Автор доходить висновку, та обгрунтовує його, що найпродуктивнішою та найперспективнішою постає цілісна картина світу, яка грунтується на принципах об'єктивного ідеалізму. Автор приєднується до традиції розуміння буття як такого, що має іманентний Логос. Обгрунтовується пріоритет Логосу над будь-якими частковими логіками. Показано, що відомі концепти давньогрецької філософської традиції («апейрон», «Логос», «форма всіх форм») не втратили смислоутворюючої актуальності для сучасної філософської думки. Обгрунтовується світоглядна та методологічна значущість концепції «Коло кіл». Автор доходить висновку, що людина для досягнення свого справжнього щастя та успішного розвитку не тільки повинна визнати, що існує дещо Одне, але і те, що воно диктує їй, а також усім речам, які ії оточують, певну єдину обов'язкову логіку поведінки. Ми повинні визнати факт, що існує єдина Логіка, яка лежить в основі всіх численних змістовних і формальних логік.
\end{abstract}


Ключові слова: світ, конгеніальність, апейрон, логос, ідеальне, розум, людина, об’єктивний ідеалізм.

\section{RELIANCE ON THE CONGENIALITY OF IDEAS AS A CONDITION FOR CONSTRUCTING A HOLISTIC PICTURE OF THE WORLD}

Summary: Drawing on his own contemporary holistic picture of the world, the author of the article "picks up" (from the time of the emergence of philosophy) the historical "chain" of philosophical ideas, congenial, that is, close in spirit and image of thought, both to each other, and the worldview of the author himself. Such a "collection" of ideas aims to find a kind of support to confirm the author's position, as well as to further specify it.

This work necessarily involves the need to analyze and interpret the ideas selected by the author, expressed in part in a kind of original terminology that underlies the fundamental similarity of various holistic pictures of the world. The author tries to unfold and substantiate his own holistic picture of the world as a result of the analysis and synthesis of many different ideas that arose in the historical intellectual collective creativity.

The author proceeds from the principle that the world can be fully and completely known. Knowledge of the world is a vital necessity for human. The epistemological ideal to be pursued constantly is the objectivity of reality. The author concludes and substantiates that the most productive and perspective is a holistic picture of the world based on the principles of objective idealism. The author adheres to the tradition of understanding being as having an immanent Logos. Logos' priority over any partial logic is justified. It is shown that the well-known concepts of the ancient Greek philosophical tradition ("apeiron", "Logos", "form of all forms") have not lost their meaning-making relevance for modern philosophical thought. The worldview and methodological significance of the Circle of Circles concept is substantiated. The author concludes that in order to achieve true happiness and successful development, one must not only admit that there is something One, but also that it dictates to it, as well as to all the things that surround it, a certain compulsory logic of behavior. We must acknowledge the fact that there is a single Logic that underlies all of the many substantive and formal logics.

Keywords: world, congeniality, apeiron, logos, the ideal, mind, human, objective idealism. 